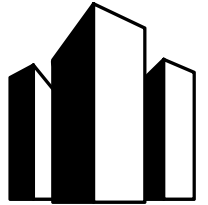

УДК 352
Аспекти публічного управління

Aspekty publichnoho upravlinnya

Public administration aspects

Public administration aspects. 2016. 37-38(11-12), 70-75. doi: $10.15421 / 15201664$

www.aspects.org.ua

\title{
Territorial community: a systematic approach to advance functions of individual elements
}

\section{T.V. Serohina ${ }^{1}$}

The feature of local governments system is absence of an extensive nationwide structure, in contrast to the system of state government. This stipulates the specific's research when it should not be viewed as a set of individual elements, but as a collection of communities, which in turn consist of a set of elements. It is determined that despite the lack of attention to the private sector as part of the local community, it plays an important role in community life. After all, businesses both provide the community with jobs and swell the budget, and create opportunities for the community, particularly to attract resources in the implementation of development strategies or reduce the costs of local projects. Like this one can not leave aside the community sector as part of the local community, because there are areas where its involvement can bring the maximum benefit, particularly in some aspects of social and cultural areas. After all voluntary of association, non-profit nature of, personal interest in solving problems in the social sector are signs of community organizations. they are the key to efficient provision of this services. It is shown that the development of social sector as a promising element of the territorial community requires state support. The support should lie not in the traditional funding narrow range of community organizations, but through the practices implementation of European countries, particularly in the direction of the delegation of authority. The specific perception of community organizations like of public associations eliminates their role as a public authority. This would give them the right to address local issues. Only in this case, they will effectively carry out their functions, including the formulation and articulation of social needs.

Revealed that successful and wealthy territorial community can only be subject to the participation of all sectors in the process of joint decision-making, and in the process of their implementation. And the responsibility for the effective cooperation of all sectors of the community should be put on local authorities.

It is established that in conditions of the administrative-territorial reform, is the need to change in the approach to the basic concepts, in particular, of the territorial communities category as well as of a new category of amalgamated territorial community. New categories need to be identifyed and be enshrined in the legal framework.

Keywords: territorial community; administrative-territorial reform; the private sector; institutions of selfgovernance of the public

\footnotetext{
${ }^{I} \mathrm{PhD}$ in public administration, associate professor; Dnepropetrovsk regional institute of public administration, the National academy of public administration under the President of Ukraine, 29, Gogol Str., Dnipro, 49044, Ukraine

${ }^{2}$ Кандидат наук з державного управління, дочент; Дніпропетровський регіональний інститут державного управління Начіональної академії державного управління при Президентові України, 49044, Дніпро, вул. Гоголя, 29

${ }^{3}$ Кандидат наук государственного управления, доцент; Днепропетровский региональный институт государственного управления Начиональной академии государственного управления при Президенте Украины, 49044, Днепр, ул. Гоголя, 29

E-mail: seregina.dridu@gmail.com
} 


\title{
Територіальна громада: системний підхід до вдосконалення функцій окремих елементів
}

\author{
T.В. Серегина ${ }^{2}$
}

Обгрунтовано, що систему місцевого самоврядування слід розглядати не як сукупність окремих елементів, а як сукупність територіальних громад, що в свою чергу складаються з набору елементів. Зазначено, що приватний сектор слід розглядати як елемент територіальної громади, адже він забезпечує громаду робочими місцями та поповнює бюджет, а також створює додаткові можливості для громади, зокрема, щодо залучення ресурсів в процесі реалізації стратегії розвитку. Доведено, що в соціальній та культурній сферах максимальний ефект в контексті надання послуг може забезпечити громадський сектор, запорукою при цьому виступають: добровільність об’єднання, неприбутковий характер діяльності, особиста зацікавленість у вирішенні проблем. 3'ясовано, що становлення громадського сектору як перспективного елементу територіальної громади вимагає підтримки держави, причому не традиційним шляхом фінансуванні статутної діяльності, а шляхом делегування повноважень. Розкрито специфіку сприйняття органів самоорганізації населення як громадських об'єднань, при цьому нівелюється їхня роль в якості органу публічної влади, що дозволяє їм вирішувати питання місцевого значення. Виявлено, що успішною та спроможною територіальна громада може бути лише за умови участі всіх секторів як в процесі прийняття спільних рішень, так і в процесі їхнього втілення в життя. Причому відповідальність за ефективну взаємодію всіх секторів громади слід покласти на місцеву владу. Встановлено, що в умовах територіальної реформи, категорія територіальної громади так само як категорія об'єднана територіальна громада потребують адекватного визначення й закріплення в нормативно-правовій базі.

Ключові слова: територіальна громада; адміністративно-територіальна реформа; приватний сектор; органи самоорганізації населення

\section{Территориальная громада: системный подход к усовершенствованию функций отдельных элементов}

\section{Т.В. Серегина ${ }^{3}$}

Обосновано, что систему местного самоуправления следует рассматривать не как совокупность отдельных элементов, а как совокупность территориальных громад, которые, в свою очередь состоят из набора элементов. Обозначено, что предпринимательский сектор следует рассматривать как элемент территориальной громады, так как он обеспечивает громаду рабочими местами и пополняет бюджет, а также создает дополнительные возможности для громады, в частности относительно привлечения ресурсов в процессе реализации стратегии развития. Доказано, что в социальной и культурной сферах максимальный эффект в контексте оказания услуг может обеспечить гражданский сектор. Залогом успешности при этом выступают: добровольный характер объединения, деятельность на неприбыльной основе, личная заинтересованность в решении проблем. Становление гражданского сектора как перспективного элемента территориальной громады требует поддержки государства, к тому же не традиционным путем финансирования статутной деятельности, а путем делегирования полномочий. Раскрыта специфика восприятия органов самоорганизации населения как гражданского объединения, при этом нивелируется их роль в качестве органа публичной власти, что позволяет им решать вопросы местного значения. Определено, что успешной территориальная громада может быть только при условии участия всех секторов как в процессе принятия решений, так и в процессе их воплощения в жизнь. При этом ответственность за эффективное взаимодействие всех секторов громады следует возложить на местную власть. Установлено, что в условиях территориальной реформы, категория территориальной громады, равно как и категория объединенной территориальной громады требуют адекватного определения и закрепления в нормативно-правовой базе.

Ключевые слова: территориальная громада; административно-территориальная реформа; предпринимательский сектор; органы самоорганизации населения

Peer-reviewed, approved and placed: 12.10 .2016

The current period of social development in Ukraine is accompanied by a processes of establishing administrative-territorial reform, so because of their importance in the process of regional democracy, is one of the priorities of state regional policy and the subject of detailed 
scientific analysis. There is investigation of possible priority areas of local government in the works of such scientists, as P. Bilenchuk, O. Bobrowska, N. Campo, O. Karlov, M. Kornienko V. Kravchenko, V. Kuybida, T. Mamatova, V. Parkhomenko, M. Pogorilo, M. Pukhtynsky, S. Seregin, Y. Sharov. However, despite the considerable scientific interest in issues the definition of status of the territorial community it has not found the appropriate coverage.

Based on the above raises the problem of developing ways to improve approaches to the concept and structure of the territorial community under current conditions the administrativeterritorial reform.

As a general sense territorial community; village, town, city council; village, town, city mayor; executive bodies of village, town or city council, mayor, district and regional councils, the BSP - components of local government [3]. However, the system of local government has not extensive nationwide structure, unlike the system of state governance, consists of individual units - the territorial communities. Therefore, despite a common regulatory framework and institutional mechanism, the emphasis should be made on the major components elements and levels of interaction between them not on a national scale, but rather the scale of a single community. It is appropriate to consider totality individual local communities as a system of local government.

Such an approach would take into account the current development priorities of territorial communities of taking into account the positions of all stakeholders in the process of decentralization. Based on it, the components of the territorial community as element of local government will be natural or legal persons or organizations that are actively involved in solving local affairs, or which affect or may affect the implementation of measures at the level of the local community.

Traditionally of attribute of effective activity of local government units is relationship with the private sector. And although it always gives local authorities additional resources and provides certain advantages, its role in the local government is reflected in a rather limited extent. Though private sector both provides the community with jobs and swell the budget, and creates opportunities for the community, particularly to attract resources in the implementation of development strategies or reduce the costs of local projects. It is noteworthy that such joint projects are characterized growth of economic indicators and increased levels of efficiency raised by local government resources.

To promote such cooperation created the Law of Ukraine «On Public Private Partnership» [2]. In a general sense, the partnership with the private sector - is the institutional and organizational alliance to implement national and international, scale and local, but always socially significant projects in a wide range of areas [5].

Implementation of the above approach regarding the perception of the private sector as part of the territorial community will help to form a joint with local authorities and residents of development prospects vision. Besides it will improve the level of social responsibility and the consequent empowerment efficient use of its potential.

However, we should not be limited to the possibilities provided by the private sector, because at the community level are the areas where the market mechanism underlying the operation of the business does not provide the desired level of efficiency, for example in some aspects of social and cultural character, because the provision of such services does not involve profit. The main issue in the provision of social services is a need of purely human manifestations of such categories as compassion, support and respect for the person. It is not provided in the case of private services institution where the person is perceived as a client.

The key to efficient provision of such services are following features of community organizations as voluntary associations, non-profit nature of, personal interest in solving problems in the social sector. However, the appropriate level of public involvement in social issues is not provided because that is traditionally limited perception of them as a full member in the system of local government. Although community organizations endowed with the special status of representative bodies [4], cooperation with local government institutions of self is impossible without ensuring an adequate level of institutionalization of forms of direct community participation in local government. For example, in Poland, according to the law «On civil benefit and volunteer service « [9], local authorities are obliged to attract community organizations to the implementation of public tasks.

However, national practice shows perception 
of community organizations formed voluntarily as directed on realization of certain interests and those who work on a voluntary basis, so, have all the features of community associations. This demonstrates the ultimate uncertainty of the role of civil sector in Ukraine, because institutional role of community organizations is not took into account the as a public authority, as defined in the law that gives them the right to address issues of local importance.

Institutional role of community organizations as a public authority requires updating among other things, the system of its functions, in particular concerning the formulation and articulation of social needs. And unlike the realization of such functions by working with public authorities through the creation of advisory bodies that mostly was of a formal nature, in this case it involves a certain procedure.

First, the community organizations are responsible on identify of a specific social need. It is important to select one that is of paramount importance. If at this stage it has sufficient resources, then the next step may be some difficulties, because it is expected promulgation of public needs so that both society and the local government learned of its existence. It is important that as a result of these steps this need was spotted and appropriately evaluated.

On the need to steps towards the implementation of the institutional role of community organizations as a public authority also show the results of surveys, as of 2014 only $9 \%$ of Ukrainian were satisfied with their ability to influence the decision of local authorities in their settlements, while $74 \%$ expressed dissatisfaction on the matter.

According to legislative norm the public organizations are element of local government, but it does not play a decisive role. Mostly cooperation with the public sector is implemented through the creation of advisory bodies, which formed by the head of public authority «for the purpose of coordinating activities related to the provision of public consultations on the formulation and implementation of public policy on important issues of social and political life of the region, the promotion of citizens regarding implementation constitutional right to participate in the management and ensure consideration of the public opinion in the process of preparing and implementation of decisions») [6].

Building an effective interaction between communities organizations with local authorities have to be realized by review of existing procedures for cooperation and funding regime. It should be noted that the State Budget of Ukraine has an article on expensed public association but it does not create the desired level of that cooperation's efficiency. Although the report states that «this form of work forces civic organizations to raise the level of their social responsibility to the state for the efficient use of taxpayers' money» [6]

However, public support is in the form of statutory funding of NGOs and access to it is enough restricted (p. 9 art. 87 of Budget Code of Ukraine). On the one hand this support is provided for public organizations, which have nationwide status, on the other hand it aims to public association of invalids and veterans. However it does not solve the existing problems because only the lion's share of that money is directed to statutory activities, mostly goes to remuneration of members.

According to above information, man can to promote revitalization of public organizations and the development it of a promising element of the territorial community. It should be done by implementing practices of European countries. The matter is that the local governance is developing in the direction of empowerment of public organizations. Unlike our national practice, when state supports their statutory activities, primarily it is toward delegation of authority. In this respect, the experience of the Polish Republic can be of great value [9].

In a general sense essence of delegation is to transfer of authority from local government public organization. There are the liability and the availability of appropriate resources (organizational, material, financial, etc.) as key delegations elements. Important that responsibility includes not only the actual commitment of the assignment, but also responsible for its satisfactory solution. As for public sector, its development requires state support because the creation of favorable conditions for attracting the public sector to solve local problems is dependent on the level of willingness to cooperate of the representative body of public authority. Though it is a basic level should be most interested in such cooperation.

Moreover, idea of public administration provides the existence of a certain ground. It is designed to become a platform for search accept- 
able to all sectors of the community solutions, it is compromise, in other words. Besides it provides search of tools for the implementation of accepted decisions and cooperation on the common good. Though the existence of this ground does not solve all the problems set. The matter is that most of these solutions do not have the scope of their practical realization. The combination of financial, organizational and administrative tools along with creating an appropriate legislative framework will facilitate cooperation processes, settlement and bringing them to the new relations level.

However man can to require special measures simultaneous participation of all communities sectors in the decision-making and later solution their joint efforts. There are harmonization, coordination, monitoring, delegation of authority, establishing contractual relations between of all communities sectors. Responsibility for this must take itself local government. Only focused and balanced approach its representatives will ensure the integrity, the interconnection and effective interaction of separate components of the whole community.

Analysis of the territorial community structure demonstrates a need to review the content of the concept territorial communities. The matter is that territorial communities, according to national legislation, is residents combined permanent residence within the village, the town, which is independent of the administrative-territorial units, or a voluntary association of residents of several villages with a single administrative center [3].

However in the course of administrative-territorial reform, which is accompanied of formation processes of amalgamated territorial communities, there is a need not only to review the content of the concept territorial communities but also correlation it with concept amalgamated territorial communities. Nevertheless there are not following definitions in the profile legal acts.

There is mention of these categories in the Budget Code of Ukraine. According to the 2 article, 2 paragraph, local government budgets are budgets of territorial community villages, their associations, towns, municipalities (including municipal districts), budgets of amalgamated territorial communities established by law and promising plan of formation territory communities. Based on this, amalgamated territorial communities, unlike territorial communities, are provided not just a totality of inhabitant, but also the territory in which they reside.

The basic categories of the local government lose it actuality in the course of administrativeterritorial reform. Similarly, the components of local government mostly should be considered not as separate components across the country, and as a set of primary subjects of the local government. This primary subject is territorial community, which is represented by the own system elements. There is private sector, the local citizens' self- organization, the local self-government bodies and other. On the one hand the local self-government bodies is elected by the people and represents community, on the other hand it is responsible for the cooperation of all sectors together. Relationship between these elements is subject to revaluation, because it formed on the basis of the existing system of self-government. The formation of public forum, where can man present all sectors of local community simultaneously, requires special attention. This is due to the fact that joint decisions will be taken whit followed by transformation into practical action in this forum.

\section{БІБЛІОГРАФІЧНІ ПОСИЛАННЯ:}

1. Бюджетний кодекс України : Кодекс України від 08 липн. 2010 р. № 2456-VI // Відом. Верховної Ради України. 2010. - № 50-51, ст. 572.

2. Про державно-приватне партнерство : Закон України від 11 липн. 2001 р. № 625-III // Відом. Верховної Ради України. -2001 . - № 48

3. Про місцеве самоврядування : Закон України від 21 трав. 1997 р. № 280/97-ВР // Відом. Верховної Ради України. - 1997. - № 24, - ст. 170

4. Про органи самоорганізації населення : Закон України від 01 липн. 2010 р. № 2404- VI // Відом. Верховної Ради України. - 2010. - № 40

5. Варнавский В. Г. Концессии в транспортной инфраструктуре : теория, практика, перспективы / В. Г. Варнавский. - М. : ИМЭМО РАН, 2002. - 189 с.

6. Громадські організації Полтави отримають вдвічі менше коштів, ніж потребували https:/tribuna.pl.ua/news/ gromadski-organizatsiyi-poltavi-otrimayut-vdvichi-menshe-koshtiv-nizh-potrebuvali/

7. Дубич К. В. Державне управління соціальними послугами: термінологічний аналіз / К. В. Дубич // Державне управління: теорія та практика. - 2014. - № 1. - С. 47-60 
8. Олексій Сидорчук, «Ставлення жителів міст до ідеї децентралізації», Фонд «Демократичні ініціативи» імені Ілька Кучеріва, 2014, № 3(23), доступно за посиланням http://dif.org.ua/modules/pages files/ 1432540363_3559.pdf. 9. Ustawa o działalności pożytku publicznego i o wolontariacie z dnia 24 kwietnia 2003 r. - Access mode. : http://www. pozytek.gov.pl/

\section{REFERENCES:}

1. Byudzhetnyy kodeks Ukrayiny : Kodeks Ukrayiny vid 08 lypn. 2010 r. № 2456-VI [Budget Code of Ukraine, the Code of Ukraine on 08 July. 2010 № 2456-VI]. 2010. Vidom. Verkhovnoyi Rady Ukrayiny 50-51, 572 (in Ukrainian).

2. Pro derzhavno-pryvatne partnerstvo: Zakon Ukrayiny vid 11 lypn. 2001 r. № 625-III [On Public-Private Partnership Law of Ukraine on July 11. 2001 № 625-III]. 2001. Vidom. Verkhovnoyi Rady Ukrayiny 48 (in Ukrainian).

3. Pro mistseve samovryaduvannya: Zakon Ukrayiny vid 21 trav. 1997 r. № 280/97-VR [On Local Government: Law of Ukraine on May 21. 1997 r. Number 280/97-VR]. 1997. Vidom. Verkhovnoyi Rady Ukrayiny 24, 170 (in Ukrainian).

4. Pro orhany samoorhanizatsiyi naselennya: Zakon Ukrayiny vid 01 lypn. 2010 r. № 2404- VI [About BSP: Law of Ukraine on 01 July. 2010 № 2404- VI]. 2010. Vidom. Verkhovnoyi Rady Ukrayiny 40 (in Ukrainian).

5. Varnavskiy, V. G., 2002. Kontsessii v transportnoy infrastrukture: teoriya, praktika, perspektivyi [Concessions in the transport infrastructure: the theory, practice, perspectives]. IMEMO RAN, Moscow (in Russian)

6. Hromads'ki orhanizatsiyi Poltavy otrymayut'vdvichi menshe koshtiv, nizh potrebuvaly [NGOs Poltava receive half the money than needed]. Access: https://tribuna.pl.ua/news/gromadski-organizatsiyi-poltavi-otrimayut-vdvichi-menshe-koshtivnizh-potrebuvali/ (in Ukrainian).

7. Dubych, K. V., 2014. Derzhavne upravlinnya sotsial'nymy posluhamy: terminolohichnyy analiz [State Department of Social Services: terminological analysis]. Derzhavne upravlinnya: teoriya ta praktyka 1, 47-60 (in Ukrainian).

8. Sydorchuk, Oleksiy, 2014. «Stavlennya zhyteliv mist do ideyi detsentralizatsiyi» [«The attitude of urban residents to the idea of decentralization»]. Fond «Demokratychni initsiatyvy» imeni Il'ka Kucheriva 3(23). Access: http://dif.org.ua/ modules/pages files/ 1432540363_3559.pdf. (in Ukrainian).

9. Ustawa o działalności pożytku publicznego i o wolontariacie z dnia 24 kwietnia 2003. Access: http://.www.pozytek.gov.pl/ 